\title{
UNCONSCIONABLE BUSINESS CONTRACTS: A DOCTRINE GONE AWRY
}

Courts and writers have often stated that "unconscionable" bargains should not and would not be enforced. ${ }^{1}$ The vague doctrine of unconscionability is applied in a variety of situations. In its simplest form, it means that contracts procured by fraud, undue influence, or duress are void. ${ }^{2}$ At another level, courts have protected widows and simpletons from the machinations of sharp traders by finding that gross inadequacy of consideration has made a contract "unconscionable" and therefore unenforceable. ${ }^{3}$ Often, use of the unconscionability doctrine reflects the removal of a given relationship from the domain of contract law. Insurance, for example, was once regarded as a field of contract. But by "interpreting" supposedly ambiguous provisions, by removing various clauses felt to be "unconscionable," and by making the inclusion of other clauses mandatory, courts and legislatures have transferred insurance into a "status" relationship." The rights and duties of the parties are no longer detemined by bargaining, but by their position in society. The buyer pays rates set by the state to a concern which is not only licensed by that state, but offers its services and writes its contracts in a manner prescribed by the state.5 Likewise, the wholly conceptual "contract" that results when an individual purchases public transportation is in fact a set of state-made rules. ${ }^{6}$ Purchase contracts between business and the isolated consumer have followed the same route. ${ }^{7}$

These results have been rationalized on the theory that the relative bargaining power of the two parties to the transaction was so unequal as to demand judicial protection of the weaker against the stronger's unconscionable "overreaching." "True or necessary as it may be, this theory contains within itself no standard of application. It has been applied indiscriminately to relations

1. E.g., 1 Corbin, Contracts $\S 128$, at $400 \mathrm{n} .94$ (1950) (citing cases).

2. See Dawson, Economic Duress-An Essay in Perspective, 45 Mich. L. Rev. 253, 262-67 (1947) (citing cases).

3. See, e.g., Jackson v. Seymour, 193 Va. 735, 71 S.E.2d 181 (1952) (widow); Thornborow v. Whitacre, 2 Ld. Raym. 1164, 92 Eng. Rep. 270 (K.B. 1794) (simpleton).

4. See Kessler, Contracts of Adhesion-Sone Thoughts About Freedom of Contract, 43 Colum. L. Rev. 629 (1943).

5. See, c.g., N.Y. Ins. LAw $\S \S 168,186$; CAL. INs. Code $\$ \S 1850-60,2071,12403$. See also Patrerson, Essentials of Insurance Law \$§ 1-8 (2d ed. 1957).

6. See Kessler, Contract as a Principle of Order, in CoHen \& CoHen, Readings in Jurisprudence \& Legal Philosophy 140, 145 (1951).

7. See Prosser, The Assault Upon the Citadel (Strict Liability to the Consuner), 69 YALE L.J. 1099 (1960).

8. See Patterson, op. cit. supra note 5 , at 3,$35 ; 1$ Corbin, Contracts $\S 128$ (1950). 
between individuals, ${ }^{9}$ between individuals and business concerns, ${ }^{10}$ or between large and small business concerns. ${ }^{11}$ Occasionally, this lack of discrimination has produced incongruous and perhaps unintended results. An illustrative case is Bisso v. Inland Waterways Corp.,$^{12}$ decided by the Supreme Court in 1955. There a barge under tow collided with a bridge pier and sank. Although the tug was found to be negligent, a release-from-liability clause in the towage contract was held by the lower courts to bar recovery by the barge. ${ }^{13}$

The Supreme Court, after analyzing seemingly haphazard precedent, ruled the challenged clause void as against public policy. The Court declared that it was merely applying to the towage industry the "general rule" voiding such clauses in "relationships such as bailors and bailees, employers and employees, public service companies and their customers." 14 Two reasons were given for the rule: discouraging negligence, and protecting "those in need of goods or services from being overreached by others who have power to drive hard bargains." 15 Justice Douglas, in a separate concurrence, contended that admiralty precedents should be the only guide to the decision, since not enough was known about the tugboat industry to make the assumption that the clause was in fact a product of superior bargaining power. ${ }^{16}$ Justice Frankfurter, in a vigorous dissent, first criticized the Court's use of the available precedent. $\mathrm{He}$ then followed Justice Douglas in finding insufficient evidence of monopoly in the towage industry, but conceded that were monopoly power found to exist, the majority result would be correct. ${ }^{17}$ The entire Court thus joined in the conclusion that the comparative bargaining power of two business entities was a relevant test of the enforceability of a contract provision, and that a clause felt to be the product of "overreaching" by the superior party would be of no effect. Leaving aside the question of whether or not the release from liability clause would actually encourage negligence, the Court's unanimous acceptance of the "unconscionability" doctrine as an alternative ground for decision seems untenable.

The Court did not attempt to give to the term "bargaining power" any specific content. All contracts, all agreements concerning goods or services, are part of a process in which some form of "bargaining power" fixes both

9. See, e.g., Schnell v. Nell, 17 Ind. 29 (1861); Schoellhamer v. Rometsch, 26 Ore. 394, 38 Pac. 344 (1894).

10. See, e.g., Collins v. Virginia Power \& Elec. Co., 204 N.C. 320,168 S.E. 500 (1933) ; Franklin Fire Ins. Co. v. Noll, 115 Ind. App. 289, 58 N.E.2d 947 (1945).

11. See, e.g., Santoro v. Central New York Power Corp;, 189 Misc. 567, 72 N.Y.S. $2 d 12$ (Sup. Ct. 1947) ; S. D: Warren Co. v. Maine Cent. Ry., 126 Me. 23, 135 Atl. 526 (1926).

12. 349 U.S. $85^{*}$ (1955). For analysis of the significance of this case in terms of admiralty law, see 69 Harv. L. Rěv. 173 (1955); Note, 42 VA. L. Rev. 77 (1956).

13. 114 F. Supp. 713 (E.D. La. 1953), aff'd, 211 F.2d 401 (5th Cir. 1954).

14. 349 U.S. at $90-91$.

15. Id. at 91 .

16. $I d$. at $97-98$.

17. Id. at $117-18$ \& n.14. 
value and rewards. ${ }^{18}$ Bargaining power, in the colloquial sense, may be only a synonym for relative demand; thus a myopic manufacturer, who in 1961 has produced seventy thousand stage-coach axles; would have very little bargaining power in an attempt to sell those axles to General Motors. Courts have rarely purported to concern themselves. with such demand-created disparities. ${ }^{19}$ Knowledge and acumen are "bargaining power" in that they give those. possessing them an advantage over those less fortunate. Judicial protection of the passive consumer in a mass market is directed against advantages of this type. ${ }^{20}$ Bargaining power may also stem from the absence of a competitive market; independent producers of crude oil might, in the absence of state action, experience some difficulty in getting their product moved over pipelines owned by the major integrated firms. ${ }^{21}$ Presumably it was this form of inequality of bargaining power that concerned the Court in Bisso. ${ }^{22}$

But even if the defendant towing company enjoyed monopoly power, the Supreme Court's invalidation of the "unconscionable" clause does not act as a substantial counterweight to the exploitation of this market advantage. An exculpatory clause such as that involved in Bisso is an allocation of risk between the parties. It may provide, for example, that if goods are damaged in transit the shipper rather than the carrier will bear the loss. ${ }^{23}$ Without such a provision, the cost of indemnifying damage claims will be a cost of business for all carriers, whether they buy insurance or self-insure. If the risk is shifted to shippers, the carrier's necessity of insuring against liability will be obviated, and their costs lowered. It is obvious that in a free market this reduction in cost will be passed on to shippers, dropping the price of the service by ap-

18. See Hale, Bargaining, Duress, and Economic Liberty, 43 CoLUM. L. Rev. 603 (1943).

19. Id. at 624. Equity, however, has sometimes refused specific performance in analogous cases where changing demand has greatly altered the value of a property beyond the scope of reasonable expectation. See, e.g., Willard v. Tayloe, 15 U.S. (8 Wall.) 557 (1869). Such protection is not, however, based on any doctrine of "unconscionability."

20. See Jacob E. Decker \& Sons v. Capps, 139 Tex. 609, 612, 164 S.W.2d 828, 829 (1942):

It is a well-known fact that articles of food are manufactured and placed in the channels of commerce, with the intention that they shall pass from hand to hand until they are finally used by some remote consumer. It is usually impracticable, if not impossible, for the ultimate consumer to analyze the food and ascertain whether or not it is suitable for human consumption.

Cf. cases cited note 3 supra.

21. See Cookenboo, Crude Oil Pipe Lines and Competition in the Oil IndusTRX 1-4 (1955).

22. The court in fact made no attempt to clarify its fear of "overreaching." But illustrations of the dangers of a contrary rule, given at 349 U.S. at 9I, together with the comments of Justices Douglas and Frankfurter, see notes 16-17 supra, indicate that some feeling that tugs had monopoly power was present.

23. In Bisso, the tug company was acting as a carrier, the barge being the item "shipped." 
proximately the cost of the insurance. ${ }^{24}$ Analytically, all other commercial contract provisions are identical to such risk-allocating clauses, in that their effect on the total balance of costs and rewards between the parties must be reflected in the price of the exchange. ${ }^{25}$ Recognition of this basic principle is of course the reason for judicial reluctance to disturb such clauses, at least where "bargaining power" is assumed roughly equivalent. ${ }^{20}$

What is not so clearly recognized, and what was totally ignored by the Court in Bisso, is that even when the release-from-liability clause is contracted for in a market that is not free, the price of the contract will still reflect its inclusion. No less than a competitor, a monopolist must take certain market and demand conditions as given. Although his market power allows him to set higher prices than those which would prevail under competition, there is still only one price at which he can maximize his profits. If the monopolist is already charging this optimal price, the inclusion of an exculpatory clause in the contract will increase the amount the customer must pay to get the goods or service, thereby raising its total price above the maximizing point. To maintain the same total price to the customer, therefore, the monopolist must lower the contract price correspondingly. ${ }^{27}$

Given this relationship between the exculpatory clause and the contract price, it is incorrect to speak of the unconscionability of the clause itself. Argument cannot be directed at the clause, but only at the total result of the contract-the price. The finding that price is too high or low is of course inherent in all decisions which find various clauses "unreasonable" or "unconscionable" since, absent illegality, there is some price at which anything will cease to be "unconscionable." Yet judges have been reluctant to legitimize this basic premise and have refused to hold the same exculpatory clause un-

24. Initially, this statement might appear in conflict with assumptions as to movements along given demand curves, with falling prices evoking larger outputs and vice versa. But in fact, the service the carrier sells to the shipper is two separate services: the transportation of goods, and insurance against loss. If he ceases to sell insurance, this will not affect the other factors which determine the price of transportation. Similarly, a decision to sell insurance will not affect the price of transport, except in so far as the carrier's position allows him to offer insurance at lower rates than those available through other commercial sources. The combined price of transport plus insurance through the carrier might then be less than that of transport through the carrier plus other insurance; but it is more correct to speak of this as lower insurance cost than lower transport cost.

25. The obvious cost allocations between the parties are those such as provisions for delivery, or the apportionment of tasks (e.g., a farmer contracting to trim stalks off carrots prior to shipment). Examples of provisions less obviously related to cost allocation would be delivery time, who bears the risk of price fluctuations after a given moment, or point of consummation of sale, who bears the risk of damage during shipment.

26. See, e.g., Globe Home Improvement Co. v. Perth Amboy Chamber of Commerce Credit Bureau, 116 N.J.L. 168, 182 Atl. 641 (Ct. Err. \& App. 1936).

27. On the validity of maximization as an assumption, see Strgler, Theory of PrICE $148-49$ (1952); Machlup, Marginal Analysis \& Empirical Research, 36 Amer. EcoN. REv. 519 (1946). 
conscionable when the transaction makes unmistakably clear that the clause is simply a part of the total contract price. For example, assume a monopolist who offers two contracts, one with an exculpatory clause, the other without, at a price differential which accurately reflects insurance cost. A court looking at the clause against this background would find that the reduced price to the shipper was a cost equivalent of the carrier's release from liability. The clause itself could not then be found to result from the inequality of bargaining power, and, good consideration having moved in the form of the price reduction, it would be upheld.28 Although the economic result of this contract is no different in essence from that deplored by the Court in Bisso, Justice Frankfurter's dissent specifically approves such option provisions. ${ }^{29}$

Far from relieving shippers of an "unconscionable" burden, the Court's action may in the long run work to their disadvantage. If exculpatory clauses are to be void in the towage industry, such clauses will disappear from all future contracts. ${ }^{30}$ In their place will be a higher price of service-higher by the towing companies' cost of insuring all shipments. Thus the decision succeeds only in making towage insurance compulsory for all shippers. It differs from a more obvious compulsory scheme in that the shipper pays his "premiums" indirectly, in the form of higher towage costs, rather than directly to an insurance company. Such judicial risk-spreading is of course quite common; but it may be useful to question whether it should be as assiduously practiced in commercial contexts as in relationships involving the general public or employees. Forcing employers, for example, to act as insurers for their employees serves certain definite social ends. It assures that employees who would probably not procure insurance themselves will not burden the state with the care of themselves or their families when they are rendered powerless to earn because of injury ; it encourages employers to intensify safety measures in an effort to lower insurance rates and thereby secure a competitive advantage. ${ }^{31}$ But shippers may have a legitimate reason for self-insuring rather than insuring commercially or through the carrier-they may prefer to run the risk of greater loss in order to obtain a greater profit. Bisso

28. Option provisions are common in the telegraph industry, where payment of a higher rate for a repeated message eliminates virtually all chance of error. See Unrepeated Message Case, 44 I.C.C. 670,675 (1917). In the telegraph case this procedure is necessitated by the practical unavailability of commercial insurance for missent messages. The application of this procedure to the Bisso context, however, is inappropriate. Unless it were shown that the "insurance" paid to the carrier were substantially lower in price than that available commercially, there is little reason to compel the carrier to offer the option.

29. 349 U.S. at 118.

30. The promptness of the draftsman's reply to judicial action is well-illustrated in insurance, where virtually every decision against an insurer has resulted in ever more ingenious rewriting. See Kessler, supra note 5, at 633; Llewellyn, Book Review, 52 HARV. L. REV. 700, 702-03 (1939).

31. See James, Accident Liability Reconsidered: The Impact of Liability Insurance, 57 Y ALE L.J. 549, 559-62 (1948). 
removes this freedom to choose the most profitable technique of insurance, and since it confers no compensating benefit on shippers as a class, its overall effect might be considered deleterious.

Of course, the Court might have believed that small businesses, like consumers and individual workers, must be protected from the consequences of their own lack of foresight and knowledge. Indeed, the majority opinion seems to regard the "unconscionability" doctrine as equally applicable to workers, consumers, and businesses. ${ }^{32}$ On its face, the analogy is badly drawn. Decision of small businessmen are probably better informed and more carefully calculated than those of any single worker or consumer. Moreover, accidents for businessmen whose capital is speculatively employed are less likely to be catastrophic. Nevertheless, the alarming rate of small business failures ${ }^{33}$ in recent years might cast doubt on the presumed competency of the small businessman. And since preservation of the small business enterprise is now recognized as a major national policy, ${ }^{34}$ courts might feel justified in protecting small businesses from their own shortcomings as an additional protective measure.

Courts which would seek to give effect to a policy of placing small business in such a "status" category, however, must determine a standard by which to identify those businesses in need of protection from themselves and others. Criteria from other areas of federal law which ostensibly protect small business, such as antitrust, tax, and government contracts, are of little assistance. The major part of "status" legislation dealing with business is contained in the antitrust laws. Simply by virtue of being large, some business enterprise is limited in certain ways ; ${ }^{35}$ by virtue of being small, other business receives

32. 349 U.S. at $90-91$.

33. In one postwar year, 1949, 370,000 businesses were "discontinued," some $9 \%$ of the $3,976,400$ business enterprises in the United States. See Survey of Current Business, June 1949, pp. 21-22; Hearings Before the Joint Committee on the Economic Rcport: Volume \& Stability of Private Investment, 81st Cong., 1st Sess. 124 (1949). Later figures show some decline in this rate. With 4,710,000 firms in operation in June 1960, business failures were running at an annual rate of 57.2 per 10,000 concerns-or roughly 270,000 failures annually. Survey of Current Business, Oct. 1960, S-5.

34. The Robinson-Patman Act, 49 Stat. 1526 (1936), 15 U.S.C. $\$ 13$ (a)-(f) (1958), supports small business at the expense of larger firms, and according to many economists, at the public expense. See, e.g., Edwards, Maintaining Competitron 156, 167-68 (1949); Adelman, Effective Competition and The Antitrust Law's, 61 HARv. L. Rev. 1289 (1948); Adelman, Integration and Antitrust Policy, 63 Harv. L. Rev. 27, 54-56 (1949). See also the Automobile Dealers' Day in Court Act of 1956, 70 Stat. 1125 (1956), 15 U.S.C. $\S \S$ 1221-25 (1958), described in Kessler, Automobile Dealer Franchises: Vertical Intcgration by Contract, 66 YALE L.J. 1135, 1171-75 (1957).

The policy of giving a larger share of government contracts to small business is codified in 15 U.S.C. $\S \S 637,644$ (1958), the effects of which are seen in Armed Services Procurement Regulations, 2 Govt. CoNT. REP. If 32130-57 (Nov. 1, 1960). For a detailed summary of government preferences for the benefit of small business, see Marcus, THE Law of SMaALl Business 13-17 (1958).

Cf. Miris, White Collar ch. 3 (1951).

35. Thus the Robinson-Patman Act, 49 Stat. 1526 (1936), 15 U.S.C. \& 13 (1958), prohibits certain large-firm pricing policies which may be necessary for maximization 
certain advantages. ${ }^{36}$ But the crucial test of antitrust enforcement is market power: how much of a given market a concern controls. ${ }^{37}$ If, however, the question is to be the need for protecting the small business against itself, the relative market power of the parties is not a relevant test. The tax laws are also of little help. For example, the benefits conferred by the Subchapter $S$ election-to-be-taxed-as-a-partnership privilege. are in fact directed at closelyheld corporations, which may be very big business indeed. ${ }^{38}$ The several concessions to small business in government contracting procedures may provide some standard of favored size. ${ }^{39}$ But, like the tax and antitrust statutes, they do not distinguish between small industry with a high degree of business acumen and those businesses in which the general level of management knowledge is little better than that of an average consumer. ${ }^{40}$ Thus, the only suitable criterion in a Bisso-type situation would seem to be the courts' estimate of whether a particular class of businessmen need judicial supervision of their business decisions.

The use of the concept of relative bargaining power, couched in terms of "unconscionability," as a guide to enforcement of contract provisions, is misleading. Redistributing resources and rewards in a given industry, if that were the aim, would require nothing short of an administrative agency with full power to write all contracts and set prices. ${ }^{41}$ Courts have repeatedly dis-

of profit, or for any attempt to expand sales. Rowe, Price Discrimination, Competition, and Confusion: Another Look at Robinson-Patman, 60 YALE L.J. 929 (1951).

36. For example, under a "market power" test of monopoly, small business may utilize certain marketing practices unavailable to their larger competitors. See, e.g., Times-Picayune Publishing Co. v. United States, 345 U.S. 594, 608-14 (1953); United States v. Jerrold Elec. Corp., CCH Trane Reg. Rep. $\llbracket 69784$ (E.D. Pa. 1960) (infant industry exception to por se tying agreement rule).

37. See Att'y Gen. Nat'l Comm. Antrtrust Rep. ch. 7 (1955).

38. See INT. Rev. CoDE of 1954, $\$ 1371$ (small business corporation one with less than 10 shareholders). There is some benefit to small corporations in that the $22 \%$ surcharge applies only to taxable income in excess of $\$ 25,000$, but this benefit is similarly available to large enterprises, e.g., a chain of retail stores, which may avail themselves of multiple surtax exemptions by the use of separate corporations for each outlet.

39. See note 34 supra.

40. See, e.g., Armed Services Procurement Regulations, 2 Gov't Cont. Rer. $\Uparrow 32131$, $\$ 1.701-1$ (Nov. 1, 1960).

41. The availability of such an agency defeated a later claimant's attempt to rely on Bisso. In S. W. Sugar \& Molasses Co. v. River Terminals Corp., 360 U.S. 411 (1959), a contract similar to that adjudicated in Bisso was filed with the ICC, to whose jurisdiction the carrier was subject. The Court ruled that the ICC, an expert administrative agency, would be able to determine whether in this case "overreaching" was actually present.

From time to time, proposals have been made for special agencies with the power to rewrite all standardized contracts, see, e.g., Sales, Standard Form Contracts, 16 Mod. L. REv. 318, 337 (1953), and presumably nonstandardized contracts as well, since evasion would be too simple otherwise.

In 1940, the putative Lochinvar of American small business, Congressman Wright Patman, introduced a bill that would have required all automobile dealer franchise contracts to be submitted to the FTC for approval and policing as to fairness. Kessler, supra note 34, at 1172; Note, 63 HARv. L. REv. 1010, 1022 (1950). 
claimed either ability or intention to assume the functions of such an agency. ${ }^{\mathbf{4 2}}$ If the question is not a reallocation, but simply the protection of small business from its own decisions, then bargaining power vis-à-vis any other business is of no consequence. The court feels that one party has been left with a choice he is unqualified to make. In a commercial setting, the doctrine of "unconscionability" camouflages what is essentially a judicial determination of proper business policy.

42. With a power of termination at will here so unmistakeably expressed, we certainly cannot assert that a limitation of good faith was anything the parties had in mind. Such a limitation can be read into the agreement only as an overriding requirement of public policy. This seems an extreme step for judges to take. ... [G]enerally speaking, the situation arises from the strong bargaining position which economic factors give the great automobile manufacturing companies; the dealers are not misled or imposed upon, but accept as nonetheless advantageous an agreement in form bilateral, in fact one-sided. To attempt to redress this balance by judicial action without legislative authority appears to us a doubtful policy. We have not proper facilities to weigh economic factors, nor have we before us a showing of the supposed needs which may lead the manufacturers to require these seemingly harsh bargains.

Bushwick-Decatur Motors, Inc. v. Ford Motor Co., 116 F.2d 675, 677 (2d Cir. 1940). 